\title{
The assessment of landslides disaster mitigation in Java Island, Indonesia: a review
}

\author{
Akhmad Zamroni ${ }^{1, *}$, Ayu Candra Kurniati ${ }^{2}$, Haris Nur Eka Prasetya ${ }^{3}$ \\ ${ }^{I}$ Department of Geological Engineering, Institut Teknologi Nasional Yogyakarta, Indonesia \\ ${ }^{2}$ Department of Urban and Regional Planning, Institut Teknologi Nasional Yogyakarta, Indonesia \\ ${ }^{3}$ Department of Mining Engineering, Institut Teknologi Nasional Yogyakarta, Indonesia
}

* Corresponding author : akhmadzamroni@itny.ac.id

Tel.:+6285692988178

Received:Feb 24, 2020; Accepted: Jul 14, 2020

DOI : 10.25299/jgeet.2020.5.3.4676

\begin{abstract}
The frequency of landslides and the fact that a large number of people live in the landslides-prone areas lead to a high death toll in Java Island, Indonesia - over 1,112 people in the period between 1999 and 2005. Indonesian National Disaster Management Agency (Badan Nasional Penanggulangan Bencana [BNPB]) reported 2,766 landslides that occurred in Java from 2014 to 2019, with 662 deaths. From its state, it looks as if Indonesia 's disaster mitigation is still weak. It is very essential to a deep understanding of landslides disaster mitigation weakness in Indonesia with the approach of governments, researchers, and local communities action. This research is a review of landslides disaster mitigation in Java Island with the approach of governments, researchers, and local communities action. Furthermore, the purpose of this study is to highlight the driving forces of landslides disaster mitigation in Java Island, Indonesia.

From the assessment of each stakeholder (government, researchers, and local communities), the driving forces of landslides disaster mitigation in Java Island are the central government has commanding disaster management activities to local governments. However, the implementation of landslides disaster mitigation at the regional level has some obstacles such as the lack of residential development planning.Many landslide research results have only become scientific papers but the landslides-prone areas have not been fully paid attention by the local government such as the absence of landslide danger warning signs.In addition, the level of preparedness and awareness among local communities is not constant at any given time. Usually, community preparedness levels can be high following a disaster. It is likely, however, to diminish over time.
\end{abstract}

Keywords: Landslides, Mitigation, Government, Researcher, Local community

\section{Introduction}

Landslides are natural disasters that harm humans and the economy both from natural events and human activities. Losses from landslides are often greater than other natural disasters such as windstorms, floods, and earthquakes (Hadmoko et al., 2017). Landslides in Indonesia are often caused by earthquakes and high rainfall (Cepeda et al., 2010). In addition, tropical climate conditions in Indonesia are also a cause of high landslides in the area (Faris and Fathani, 2013). According to data from the Geological Agency of Indonesia, landslides in Indonesia caused 32 fatalities per incident. In addition, the annual frequency of landslides in Indonesia from 1981 - 2007 was 49 times landslides per year. The total victims from Indonesian landslides are Sumatra (18\%), Sulawesi (24\%), and Java (52\%). Landslides in Indonesia cause infrastructure damages such as roads and agriculture (Cepeda et al., 2010).

Java is known as a volcanic Island that produces materials from active or ancient volcanoes because of its location in the active boundary of two plates (Smyth et al., 2005). Subduction in Java has effects on its geological history. Oblique subduction in Java is characterized by features such as displaced and fragmented terraces, major strike-slip faults, folding, and thrusting (Hall et al., 2007). Landslides often occur in Java that has mountainous areas and a wet tropical climate. A number of factors supporting the occurrence of landslides in Java are as follows: firstly, Java has rugged terrain consisting of cliffs, hills, and mountains; secondly, from October to April, heavy rainfall is prevalent; thirdly, 36 of 129 Indonesian volcanoes are located in Java, producing highly weathered volcanic materials (Christanto et al., 2009).

The frequency of landslides and the fact that a large number of people live in the landslides-prone areas lead to a high death toll in Java Island, Indonesia - over 1,112 people in the period between 1999 and 2005 (Hadmoko et al., 2010). Indonesian National Disaster Management Agency (Badan Nasional Penanggulangan Bencana [BNPB]) reported 2,766 landslides that occurred in Java from 2014 to 2019, with 662 deaths (http://bnpb.cloud/dibi/tabel1a). From its state, it looks as if Indonesia 's disaster mitigation is still weak.

Geological information is of great importance given to public officials, politicians, business leaders, and the media or the general public. The geological disciplines that have a lot to do with society are the fields of disaster, where they should have the motivation of knowledge about disaster mitigation to reduce the occurrence of risks (Stewart and Gill, 2017). It is necessary to explore how social science can be integrated into geological disciplines like in disaster mitigation fields. Disaster mitigation is a method to reduce the risk or effect of a disaster by preemergency or disaster acts. Disaster mitigation is based on potential risks and impacts, and causes (human or natural factors) so that mitigation does not increase vulnerability to other risks (Public Safety Canada, 2015).

Some previous studies about social sciences of landslides disaster mitigation in Indonesia have been conducted in the last decade such as community-based risk reduction effort 
(Karnawati et al., 2011), socio-technical approach for landslides risk reductionand disaster mitigation program (Karnawati et al., 2013), driving factors of social vulnerability (Siagian et al., 2014), the quantitative research of public perception of disaster landslides (Suharini et al., 2014), and the communication problems between scientists and executives on the one hand and societies on the other (Andreastuti et al., 2017). It is also very essential to a deep understanding of landslides disaster mitigation weakness in Indonesia with the approach of governments, researchers, and local communities action. This research is a review of landslides disaster mitigation in Java Island with the approach of governments, researchers, and local communities action. Furthermore, the purpose of this study is to highlight the driving forces of landslides disaster mitigation in Java Island, Indonesia.

\section{The stakeholders of landslides disaster mitigation in Indonesia}

Some stakeholders are involved in landslides disaster mitigation include the government or policymakers, practitioners, researchers, students, and the local community (Margottini et al., 2013). The stakeholders of landslides disaster mitigation in this research focus on governments or policymakers, researchers, and local communities. Policymaker in the landslides disaster mitigation is a member of a government department or organization that is responsible to establish of structural and or nonstructural mitigation, create a priority to protect important assets, and measure a cost-benefit ratio in the mitigation technique (Samodra et al., 2018).

Within the scope of governments, the Indonesian National Disaster Management Agency (Badan Nasional Penanggulangan Bencana [BNPB]) is the main actor involved in providing direction, guidance, standards, and disaster management requirements (Srikandini et al., 2018). BNPB's tasks include formulating and establishing disaster management policies and assisting refugees, and commanding disaster management activities. BNPB has a disaster management subagency at the Regency or City and Provincial level called the Regional Disaster Management Agency (Badan Penanggulangan Bencana Daerah [BPBD]) (BNPB, 2017). Therefore, BPBD is responsible for supporting the efficacy of emergency recovery initiatives at the provincial and district level (Karnawati et al., 2013).

In the scope of researchers, The Center for Volcanology and Geological Hazard Mitigation (Pusat Vulkanologi dan Mitigasi Bencana Geologi [PVMBG]) is one of the units within the Geology Agency Ministry of Energy and Mineral Resources formed to conduct research, investigations, engineering, and services in the field of volcanology and geological disaster mitigation (Kementerian Energi dan Sumber Daya Mineral Badan Geologi, 2016). In addition, universities are also involved in landslide disaster mitigation research. Meanwhile, local communities in the landslides disaster mitigation are people who stay in the landslides prone areas that have opportunities to reduce landslide disaster through some actions such as observe weather or places conditions that are dangerous, land-use planning, or work together to repair damaged properties after landslides disaster (Hewitt, 2010).

Global innovations occurred with shifts in disaster response from reactive to constructive, from singular to more systemic with an emphasis on Disaster Risk Reduction ( DRR), and from a state-centered model to forms of co-governance that understand the significance of the participation of non-state actors in disaster management and of community-based resilience and initiatives (Srikandini et al., 2018). Meanwhile, good disaster management should be shared by multiple state and non-state actors in a country to allocate the required resources, make disaster risk mitigation a political priority, ensure and enforce its implementation and delegate responsibility for deficiencies, and encourage the involvement of all relevant stakeholders (UNISDR, 2004). The commitment of the local community and local government should increase disaster risk reduction. In addition, it is essential to conduct regular audits and analyses of the involvement of relevant stakeholders so that the landslides disaster mitigation system will be better (Fathani et al., 2016).

\section{The assessment of stakeholders action}

\subsection{Governments action}

BNPB mostly works on a national scale mapping landslide areas. BNPB makes a guideline in determining of disaster risk assessment. The contents of the document are in determining disaster risk assessment must use three main parameters, namely the index of capacity, vulnerability, and hazard. The index of capacity is based on government preparedness in disaster preparedness, mitigation, disaster education, and early warning. Vulnerability is based on physical, economic, social and environmental losses caused by disasters. While hazard is based on the potential and impacts resulting from disasters (Basofi et al., 2018). In addition, one of BNPB's policies is creating Safe School Disaster to increase student awareness so that they have a good plan during and after the disaster, and are always responsive in responding to disaster emergencies (Husna and Fauzi, 2019).

Based on literature reviews relating to BPBD conditions in several regions in Java, in the scale of local government, BPBD conducted activities such as awareness-raising about the disaster and formed The Formation of Risk Disaster Reduction Forum (Forum Pengurangan Risiko Bencana [FPRB]) in the village-level whose members are man and woman citizens, village functionaries, and teenagers. BPBD cooperated with FPRB conducted activities in disaster introduction, monitoring of treating disaster development, installing danger alerts, risk management, treating high-risk analysis, and disaster risk identification. The problem faced by FPRB is limited funds because donations are only obtained from village funds and FPRB only works waiting for direction from BPBD (Wardani and Putra, 2016).

Some weaknesses of BPBD in several regions in Java such as BPBD did not install signs warning of landslide hazards in the landslides prone areas, BPBD did not oversee spatial planning activities and did not oversee building construction permits, BPBD did not make special building structures that function to prevent landslide impacts, BPBD did not relocate residents living in the landslides prone areas (Suharini et al., 2014), and BPBD has not performed optimally to incorporate awareness, education, and creativity to create a culture of endurance and safety at all village levels (Wardani and Putra, 2016). However, BPBD also carried out repairs to infrastructure damaged because of landslides by using state budget, and BPBD has restored social-psychological conditions to eliminate the trauma of landslide victims (Suharini et al., 2014).

\subsection{Researchers action}

The Center for Volcanology and Geological Hazard Mitigation (Pusat Vulkanologi dan Mitigasi Bencana Geologi [PVMBG]) has a landslides disaster mitigation sector that has the tasks of preparing technical policy, norms, standards, procedures, criteria, plans, reporting, mapping, technical 
recommendations for landslides disaster mitigation, research, investigation, engineering, monitoring and early warning, hazard modeling, and dissemination of landslides information (Kementerian Energi dan Sumber Daya Mineral Badan Geologi, 2016). PVMBG determines the red zone area, which is an area that often occurs mass movement (Iskandar et al., 2018). Some universities use maps of estimated areas of landslides created by PVMBG for their research, for example, recently, the School of Environmental Science, Universitas Indonesia conducted a study about landslide vulnerability in residential areas, Sawangan District, Depok City (Puspitasari and Herdiansyah, 2019). In addition, many studies have been carried out by universities on landslides disaster mitigation such as; 1) researchers from The Department of Civil and Environmental Engineering and the Department of Geological Engineering at Gadjah Mada University conducted a report on an Integrated Methodology to establish a framework for early warning landslide systems. They introduced a new model consisting of seven early warning sub-systems, namely the installation of monitoring and alert services, uniform operating procedures, the creation of an evacuation map, the establishment of a disaster preparedness and response team, distribution and communication, risk assessment and mapping, and local participation in the operation, and maintenance of all the program (Fathani et al., 2016), 2) researchers from the Department of Environmental Geography, Gadjah Mada University, and the Graduate School of Civil and Structural Engineering, Kyushu University, conducted a report on the participatory mapping of landslide inventories. They mixed the conventional geomorphological field survey approach requiring active community engagement with the use of advanced technologies to locate and quantify the severity of past landslides, such as GPS and laser range finder. Participatory inventory mapping of landslides is a costeffective, reliable, and often the most feasible approach to use in a small data set, for example in Indonesia. The strategy will endorse countermeasure tools to protect citizens, properties, buildings, and facilities from landslide hazards by developing effective land-use planning (Samodra et al., 2018), 3) Researchers from the Institute of Technology Bandung, Department of Geophysical Engineering conducted a study using the resistivity test in Bandung, West Java to define the possible ground movement as a landslide disaster mitigation strategy. The result was a possible landfill zone on Jalan Citra Green, Dago with a low resistivity region below the soil. (Izzati et al., 2017).

\subsection{Local communities action}

Community awareness is needed to reduce disaster risk in accordance with social, economic and local cultural conditions. Continuing training and education programs on natural disaster mitigation can increase public awareness. This activity will increase community knowledge to prevent landslides and protect themselves if there are landslides in the future (Fathani et al., 2016). Local communities' actions are one of the factors causing landslides. These actions are not only the actions that they take in developing residential areas but also the lack of awareness of landslides disaster mitigation. Residential areas have increased recently. Many local communities build houses on the plains, surrounded by steep slopes. Many settlements are built under roads or on hillsides. This condition will support the occurrence of landslides. It means that the construction of residential areas often does not consider the possibility of natural disasters such as landslides (Wati et al., 2010).

Regional disaster mitigation landslides are more likely to save and evacuate activities. Obstacles to community efforts to overcome landslides are limited early warning systems, limited funds for the construction of mitigation facilities, or limited land for making embankments, rainwater channels, and planting plants firmly rooted (Suharini et al., 2014).

The level of preparedness and awareness among local communities is not constant at any given time. Usually, community preparedness levels can be high following a disaster. It is likely, however, to diminish over time.Monitoring and alarm systems sustaining continue to be ignored as community awareness declines. All interested parties should develop early warning landslide systems that last not only for the short term (1-2 years) but also continuously. The development of the landslides disaster mitigation will not stop the landslide from occurring, but it does provide warnings to local communities. Knowledge of local communities is expected to be increased, and as such people will be able to independently conduct mitigation (Fathani et al., 2016).

\subsection{The driving forces of landslides disaster mitigation in Java Island, Indonesia}

From the assessment of each stakeholders (government, researchers, and local communities), the driving forces of landslides disaster mitigation in Java Island are the central government has commanding disaster management activities to local governments. However, the implementation of landslides disaster mitigation at the regional level has some obstacles such as the lack of residential development planning. It means there are still many settlements in landslides-prone areas. Besides, there is limited training and education of landslides disaster mitigation for people living in landslides-prone areas. Researchers have conducted a lot of landslide research that can be used as a landslide disaster mitigation. However, many research results are not applied for mitigation and are not disseminated to the public. Many landslide research results have only become scientific papers. Universities in Indonesia have the task to conduct "Tri Dharma" which means three tasks that must be conducted by lecturers in the universities namely teaching, research, and charity. The lecturer also works as a researcher, some of the lecturers' research results can be applied to charity activities but there is no data that mentions how many the results of lecturer research that has been applied to the community.

PVMBG as the units formed to conduct research, investigations, engineering, and services in the field of volcanology and geological disaster mitigation has conducted research activities in the field of landslides. PVMBG's website also recorded data on landslides-prone areas that can be accessed by the public. However, the landslides-prone areas have not been fully paid attention by the local government such as the absence of landslide danger warning signs. While there are still many casualties in each landslide disaster, it is estimated that public awareness of landslides disaster mitigation is still very low. In addition, there are still many local communities who live in landslides-prone areas because there are no regulations from the government regarding this matterand limited land to build landslide mitigation buildings such as embankments and rainwater channels. Fig. 1. shows a diagram of the driving forces of landslides disaster mitigation in Java Island, Indonesia. 


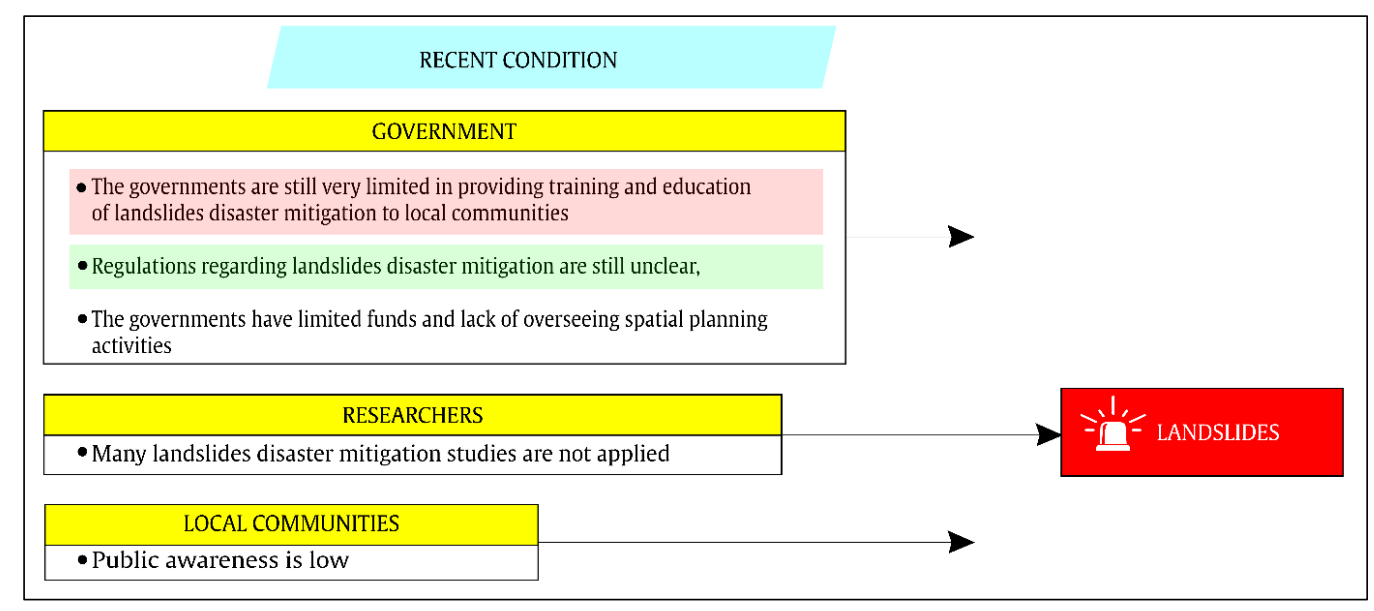

Fig 1. shows a diagram of the driving forces of landslides disaster mitigation in Java Island, Indonesia.

\section{Conclusions}

The driving forces of landslides disaster mitigation in Java Island, Indonesia are; 1) the governmentsare still very limited in providing training and education of landslides disaster mitigation to local communities, 2) regulations regarding landslides disaster mitigation are still unclear, 3) the governments have limited funds and lack of overseeing spatial planning activities, 4) many landslides disaster mitigation studies are not applied, 5) public awareness of local communities to landslides disaster mitigation is low.

\section{Acknowledgements}

The authors would like to appreciate to Institut Teknologi Nasional Yogyakarta, Indonesia in providing the best place to conduct this research.

\section{References}

Andreastuti, S., Budianto, A. and Paripurno, E.T., 2017. Integrating social and physical perspectives of mitigation policy and practice in Indonesia. In Observing the Volcano World (pp. 307-320). Springer, Cham.

Basofi, A., Fariza, A. and Safitri, E.I., 2018, November. Landslide Risk Mapping in East Java, Indonesia, Using Analytic Hierarchy Process-Natural Breaks Classification. In 2018 International Seminar on Research of Information Technology and Intelligent Systems (ISRITI) (pp. 77-82). IEEE.

BNPB,2017. Natural Disasters in Indonesia. URL http://bnpb.cloud/dibi/tabel1a(accessed 02.24.20).

BNPB, 2017. Tasks and Functions of BNPB. URL https://www.bnpb.go.id/en/hometugas (accessed02.24.20).

Cepeda, J., Smebye, H., Vangelsten, B., Nadim, F. and Muslim, D., 2010. Landslide risk in Indonesia. Global assessment report on disaster risk reduction, ISDR.

Christanto, N., Hadmoko, D.S., Westen, C.J., Lavigne, F., Sartohadi, J. and Setiawan, M.A., 2009. Characteristic and behavior of rainfall induced landslides in Java Island, Indonesia: an overview. EGUGA, p.4069.

Faris, F. and Fathani, F., 2013. A coupled hydrology/slope kinematics model for developing early warning criteria in the Kalitlaga Landslide, Banjarnegara, Indonesia. In Progress of Geo-Disaster Mitigation Technology in Asia (pp. 453-467). Springer, Berlin, Heidelberg.

Fathani, T.F., Karnawati, D., Wilopo, W. and Crowley, K., 2016. An integrated methodology to develop a standard for landslide early warning systems. Natural Hazards \& Earth System Sciences, 16(9).
Hadmoko, D.S., Lavigne, F. and Samodra, G., 2017. Application of a semiquantitative and GIS-based statistical model to landslide susceptibility zonation in Kayangan Catchment, Java, Indonesia. Natural Hazards, 87(1), pp.437-468..

Hall, R., Clements, B., Smyth, H.R. and Cottam, M.A., 2007. A new interpretation of Java's structure.

Hewitt, K., 2010. Gifts and perils of landslides: catastrophic rockslides and related landscape developments are an integral part of human settlement along upper Indus streams. American Scientist, 98(5), pp.410-419.

Husna, I.H. and Fauzi, A., 2019, April. Analysis of the initial capabilities of students to landslide disasters. In Journal of Physics: Conference Series (Vol. 1185, No. 1, p. 012083). IOP Publishing.

Iskandar, R., Budhi, I.P., Andriani, T., Muslim, D. and Zakaria, Z., 2018, July. Probabilistic analysis in revealing of landslides triggering factors in Cisampih, Sumedang, West Java. In AIP Conference Proceedings (Vol. 1987, No. 1, p. 020058). AIP Publishing LLC.

Izzati, F.N., Laksmana, Z.S., Marcelina, B., Hutabarat, S.S. and Widodo, 2017, July. Identifying potential ground movement as a landslide mitigation approach using resistivity method. In AIP Conference Proceedings (Vol. 1861, No. 1, p. 030046). AIP Publishing LLC.

Karnawati, D., Fathani, T.F., Ignatius, S., Andayani, B., Legono, D. and Burton, P.W., 2011. Landslide hazard and community-based risk reduction effort in Karanganyar and the surrounding area, central Java, Indonesia. Journal of Mountain Science, 8(2), pp.149153.

Karnawati, D., Maarif, S., Fathani, T.F. and Wilopo, W., 2013. Development of socio-technical approach for landslide mitigation and risk reduction program in Indonesia. ASEAN Engineering Journal Part C, 2(1), pp.22-49.

Kementerian Energi dan Sumber Daya Mineral Badan Geologi,2016. Tasks and Functions. URL https://vsi.esdm.go.id/index.php/tentangpvmbg/fungsi(accessed 02.24.20).

Margottini, C., Canuti, P. and Sassa, K., 2013. Landslide science and practice (Vol. 1). Berlin: Springer.

Public Safety Canada, 2015. About disaster mitigation. URL https://www.publicsafety.gc.ca/cnt/mrgncmngmnt/dsstr-prvntn-mtgtn/bt-dsstr-mtgtn-en.aspx (accessed04.28.19).

Puspitasari, P. and Herdiansyah, H., 2019, December. Landslide Vulnerability in Residential Areas for Disaster 
Mitigation in Sawangan District, Depok City. In Journal of Physics: Conference Series (Vol. 1339, No. 1, p. 012091). IOP Publishing.

Samodra, G., Chen, G., Sartohadi, J. and Kasama, K., 2018. Generating landslide inventory by participatory mapping: an example in Purwosari Area, Yogyakarta, Java. Geomorphology, 306, pp.306-313.

Siagian, T.H., Purhadi, P., Suhartono, S. and Ritonga, H., 2014. Social vulnerability to natural hazards in Indonesia: driving factors and policy implications. Natural hazards, 70(2), pp.1603-1617.

Smyth, H., Hall, R., Hamilton, J. and Kinny, P., 2005. East Java: Cenozoic basins, volcanoes and ancient basement.

Srikandini, A.G., Hilhorst, D. and van Voorst, R., 2018. Disaster risk governance in Indonesia and Myanmar: The practice of co-governance. Politics and Governance, 6(3), pp.180-189.

Stewart, I.S. and Gill, J.C., 2017. Social geology-integrating sustainability concepts into Earth sciences. Proceedings of the Geologists' Association, 128(2), pp.165-172.

Suharini, E., Dewi Liesnoor, S. and Kurniawan, E., 2014. Public perception of disaster landslides and efforts to overcome in subdistrict kaloran central java
Indonesia. Universal Journal of Geoscience,2(7), pp.195-199.

UNISDR, 2004. Disaster risk reduction, governance and development. Geneva: United Nations International Strategy for Disaster Risk Reduction.

Wardani, N.R. and Putra, D.F., 2016, November. Strengthening Local Capacity in Disaster Risk Reduction (Case Study: Disaster Resilient Village in Batu City, East Java, Indonesia). In lst International Cohference on Geography and Education (ICGE 2016). Atlantis Press.

Wati, S.E., Hastuti, T., Widjojo, S. and Pinem, F., 2010. Landslide susceptibility mapping with heuristic approach in mountainous area: A case study in Tawangmangu sub district Central Java, Indonesia. International archives of the photogrammetry, remote sensing and spatial information science, 38(Part 8).

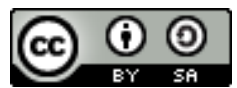

(C) 2020 Journal of Geoscience, Engineering, Environment and Technology. All rights reserved. This is an open access article distributed under the terms of the CC BY-SA License (http://creativecommons.org/licenses/by-sa/4.0/). 